\title{
Aralama şiddetinin dar yapraklı dişbudak odununun emprenye edilebilirliğine (retensiyon) ve yoğunluğuna etkisi
}

\section{The effect of thinning intensity on impregnability (retention) and density of narrow leaved ash wood}

\author{
Mesut YALÇIN ${ }^{1}$, Ali Kemal ÖZBAYRAM ${ }^{2}$, Çağlar AKÇAY ${ }^{1}$, Emrah ÇiçEK ${ }^{2}$ \\ ${ }^{1}$ Düzce Üniversitesi Orman Fakültesi Orman Endüstri Mühendisliği Bölümü Düzce, Türkiye \\ 2Düzce Üniversitesi Orman Fakültesi Orman Mühendisliği Bölümü Düzce, Türkiye
}

\section{Eser Bilgisi / Article Info}

Araştırma makalesi / Research article

DOI: $10.17474 /$ artvinofd.397804

Sorumlu yazar / Corresponding author Çağlar AKÇAY

e-mail: caglarakcay@duzce.edu.tr ORCID: 0000-0003-1246-3056

Geliş tarihi / Received
23.02.2018
Düzeltme tarihi / Received in revised form
05.11.2018
Elektronik erişim / Online available
18.11.2018

Anahtar kelimeler:

Gövde yönü

Kesit yüksekliği

Dişbudak

Yoğunluk

Emprenye edilebilirlik

Keywords:

Stem direction

Section height

Ash

Density

Impregnability

\begin{abstract}
Özet
Bu çalışmanın amacı, dişbudak (Fraxinus angustifolia Vahl) plantasyonunda uygulanan farklı şiddetteki aralamaların kesit yüksekliğine ve gövde yönüne göre emprenye maddesinin retensiyon miktarı ve yoğunluk değişimine etkilerinin araştırılmasıdır. Bu amaçla dişbudak odunlarından aralamanın yapıldığı son yedi yıllık bölümden, yedi kesiş yüksekliğinden ve kuzey ve güney olmak üzere iki farklı gövde yönünden örnekleme yapılmıştır. Elde edilen sonuçlara göre, odunun yoğunluğu ile emprenye maddesinin retensiyon miktarı arasında zıt yönlü bir ilişki olduğu tespit edilmiştir. Yoğunluk ve retensiyon miktarı bakımından doğal ve şiddetli aralama yapılan örnekler arasında farklılık olduğu, şiddetli aralama yapılan örneklerde yoğunluk azalmakta iken retensiyon miktarında artış olduğu görülmektedir. Ayrıca, gövdenin alt kısmından tepe kısmına doğru ilerledikçe odun yoğunluğunda \%25'e varan artış meydana gelirken, retensiyon miktarında \%30'lara varan azalma tespit edilmiştir. Gövde yönünün etkisi irdelendiğinde ise, gövdenin kuzeye bakan kısmının güneye bakan kısmına göre daha yoğun olup, retensiyon miktarı bakımından daha az kuru emprenye maddesi absorpladığı tespit edilmiştir.
\end{abstract}

\begin{abstract}
The aim of this study was to investigate the effects of different intensities thinning in the ash (Fraxinus angustifolia Vahl) plantation on the retention amount of impregnation material and density variation according to section height and stem direction. For this purpose, samplings were made from the last seven years thinning section, seven section height and two different stem direction (north and south). According to results, a negative correlation was detected between wood density and retention amount of treatment solution. In terms of density and retention amount, there were differences between natural and intensity thinning samples and it was seen that the density was decreased while retention amount was increased in intensity thinning samples. In addition, wood density was increased up to $25 \%$ while retention amount was decreased up to $30 \%$ as it progressed from bottom of wood to top. When the effect of stem direction was considered, it was found that south section of wood was more dense than north side and retention values has lower.
\end{abstract}

\section{GiRiş}

Son yıllarda, dünyada endüstriyel odun hammaddesinin karşılanması için ağaçlandırma çalışmaları ve plantasyon ormanlarının kurulması için çalışmalar yoğunlaşmıştır. Ağaçlandırma çalışmalarında ise hızlı yetişen türler tercih edilmektedir. Ayrıca çeşitli ıslah çalışmaları ve silvikültürel müdahaleler ile birlikte hem artım yükseltilmekte hem de kaliteli odun gövdesi elde edilmeye çalışılmaktadır (Güller ve Gürlevik 2005).

Dar yapraklı dişbudak (DYD; Fraxinus angustifolia Vahl) hızlı gelişme özelliği ve değerli odunu nedeniyle Avrupa'da önemi giderek artan ağaç türlerinden biridir (Fraxigen 2005; Gerard ve ark. 2006; Kremer ve ark.
2006). Ayrıca dişbudak, bükme ve masif mobilya üretiminde, kaplama, spor aletlerinden raket, bilardo masası, hokey sopası, sandal kürekleri, gemi omurgasında, uçak ve yatların masif kısımlarının üretiminde geniş yıllık halkalara sahip odunları ise karoser yapımında kullanılmaktadır (Merev 1984; Bozkurt ve Erdin 1995; Şahin ve Güler 2015).

DYD Güney Avrupa, Balkanlar, Kafkaslar, İran ve Kuzey Afrika'da doğal olarak bulunur (Boshier ve ark. 2005). Bu tür, Türkiye'nin ekolojik olarak farklı bölgelerinde geniş bir doğal yayılışa sahiptir (Yaltırık 1978) ve özellikle ülkenin kuzey kıyı bölgelerinin taban arazideki ormanlarına hakimdir (Çiçek 2004; Cicek ve ark. 2013). Ancak, 
Türkiye'de, DYD hâkimiyeti altındaki doğal taban ormanlarının hemen hemen tamamı son 50 yılda saf DYD plantasyonlarına dönüştürülmüştür.

Türkiye'de 7.2 bin hektar alanda dişbudak yayılış yapmakta bunun yaklaşık yarısı (3.5 bin ha) Adapazarı yöresinde bulunmaktadır (Anonim 2015). Yöredeki plantasyonları iki grup halinde ele almak mümkündür. Birinci grubu 1666 ve 1333 adet ha-1 $^{-1}(3 \times 2$ ve $3 \times 2.5 \mathrm{~m}$ ) dikim sıklıkları ile 1965-1978 yılları arası dönemde kurulan meşcereler; ikinci grubu ise 750-625 adet ha ${ }^{-1}$ (3.65×3.65$4 \times 4 \mathrm{~m}$ ) arasında değişen dikim sıklıklarının kullanıldığı, 1981-1985 dönemde kurulan meşcereler oluşturmaktadır. Bu plantasyonların büyük çoğunluğunu ikinci grup meşcereler oluşturmaktadır (Çiçek 2002).

Bilindiği gibi dişbudak odunu dış ortamlarda biyotik faktörlere karşı doğal dayanımı istenilen düzeyde olmayıp, kolayca bozunabilme özelliğine sahip bir türdür (Şahin ve Güler 2018). Çürüklük mantarları ve Anobium punctatum ve Lyctus brunneus odun zararlısı böceklere karşı odunu oldukça hassastır (Kaygın 2007; Yalçın ve Şahin 2015). Bu nedenle özellikle dış ortamlarda kullanılması durumunda çeşitli odun koruyucu kimyasal maddeler ile emprenye edilmesi kullanım ömürünü arttıran en etkili yollardan birisidir. Ancak bir emprenye uygulamasının başarıı sayılabilmesi için emprenye çözeltisinin oduna derinlemesine nüfuz etmesinin yanı sıra aktif koruyucunun oduna tutunması gerekmektedir. Ahşap malzemenin bünyesine aldığı kuru emprenye maddesi miktarına "retensiyon miktarı" olarak adlandırımaktadır (Richardson 1978).

Yoğunluk, masif ve lifsel (kağıt, lif levha vb.) ahşap ürünlerin hem verimliliği hem de kalitesi üzerinde en önemli özelliklerden birisidir (Zobel 1963; Barefoot ve ark. 1970; van Buijtenen 1982). Yoğunluk üzerinde etkili en önemli faktörler ise, odundaki madde miktarı, hacmi ve rutubet miktarıdır (Jessome 1977).

Bu çalışmanın amacı 3.7x3.7 m dikim aralığıyla kurulmuş DYD plantasyonunda uygulanan farklı şiddetteki aralamaların ağaç gövdesi boyunca retensiyon ve yoğunluk değişimine yedi yıllık etkilerini belirlemektir.

\section{MATERYAL VE YÖNTEM}

\section{Dişbudak Ağaçlarının Seçimi}

Araştırmaya konu plantasyon Adapazarı Orman Bölge Müdürlüğü, Hendek Orman İşletme Müdürlüğü, Süleymaniye Orman İşletme Şefli sınırları içerisinde, 151 numaralı bölmede yer almaktadır (4048' N, 3033' E, 25 m). Sahanın yükseltisi $25 \mathrm{~m}$ kadar olup oldukça düz bir arazide bulunmaktadır. Saha derin alüvyal topraklı ve zayıf drenajlıdır. Taban suyu Şubat-Nisan ayları arasında yüzeye çıkmaktadır. Sahada yıllık yağış $846 \mathrm{~mm}$, yıllık ortalama sıcaklık $14.2^{\circ} \mathrm{C}^{\prime}$ dir.

Doğal yapıda DYD'nin hakim olduğu, karaağaç (Ulmus laevis, U. minor), meşe (Quercus robur, Q. hartwissiana) ve ova akçaağacı (Acer campestre) gibi türlerin de yer aldığı meşcereler tıraşlama kesilmiş ve dikimle saf DYD plantasyonlarına dönüştürülmüştür (Çiçek 2002). Araştırmaya konu plantasyon 1984 yılında, 1+0 yaşlı ve çıplak köklü fidanlar kullanılarak $3.7 \times 3.7 \mathrm{~m}$ dikim aralı̆̆ı (730 adet ha ${ }^{-1}$ ) ile kurulmuştur. Plantasyon 22 yaşına geldiğinde sahada kontrol, mutedil ve kuvvetli şiddette olmak üzere $40 \times 40 \mathrm{~m}\left(1600 \mathrm{~m}^{2}\right)$ ebatlarında üç farklı parsel kurulmuştur. Aralama ile göğüs yüzeyinin mutedil parselinde \%19.2'si, kuvvetli parselde ise \%28.3'ü çıkartılmıştır. Kontrol parseline ise müdahalede bulunulmamıştır.

\section{Yöntem}

Aralamadan 7 yıl sonra deneme sahalarındaki ağaçların göğüs yüksekliği çapları ölçülmüştür. Daha sonra her parselin göğüs yüzeyi orta ağacı çapını temsil eden ağaçlar belirlenmiştir. Seçilen 3 örnek ağaçlar aynı zamanda kendi sınıfında parselin büyüme özelliklerini temsil eden, gövde şekli ve tepe biçimlenmesi normal olan ağaçlardır. Önce Kuzey yönleri işaretlenen örnek ağaçlar dipten kesilmiş ve boyları ölçülmüştür. Gövde üzerindeki dallar temizlendikten sonra şerit metre yardımıyla kesit yüksekliklerinden $(0.30 \mathrm{~m}, 1.30 \mathrm{~m}, 3.30 \mathrm{~m}, 5.30 \mathrm{~m}, 7.30$ $\mathrm{m}, 9.30 \mathrm{~m}, 13.30 \mathrm{~m}$ ) yaklaşık $12 \mathrm{~cm}$ kalınlığında kesitler alındı.

Alınan kesitler laboratuvara getirildikten sonra iklimlendirme odalarında denge rutubetine gelinceye kadar yaklaşık 4 ay bekletilmiştir. Numaralandırıış kesitler atölyede önce yüzeyleri düzleştirilmiştir. Daha sonra 
kesitler üzerinde aralama kesiminin yapıldığı yıldan itibaren son yedi yıllık artım belirlenerek işaretlenmiş ve deney örnekleri belirlenen bu kısımdan hazırlanmıştır. Yoğunluk ve emprenye edilebilirlik deney örnekleri 2 (teğet) $\times 2$ (radyal) $\times 2$ (boyuna) $\mathrm{cm}$ boyutlarında hazırlanmıştır.

\section{Yoğunluk Tespiti}

Tüm varyasyonlarda test ve kontrol denemeleri için 10, her bir aralama için 140 ve toplamda 420 adet örnek kullanılmıştır.

Yoğunluk denemeleri TS 2472 standardında belirtilen esaslara göre yürütülmüştür. Buna göre deney örnekleri, $20 \pm 2^{\circ} \mathrm{C}$ sıcaklık ve $\% 65 \pm 3$ bağıl nem şartlarındaki iklimlendirme odasında değişmez ağırlığa ulaşıncaya kadar bekletilmiştir. Daha sonra örneklerin ağırlıkları 0,001 g duyarlıkta terazide tartılmış, boyutları ise 0,01 $\mathrm{mm}$ duyarlıkta kumpas ile ölçülerek hacimleri hesaplanmıştır. Hava kurusu yoğunluk değerleri eşitlik 1 yardımıyla belirlenmiştir.

$\delta \mathrm{r}=\frac{\mathrm{Mr}}{\mathrm{Vr}}$

Bu eşitlikte;

$\delta r$ : Herhangi bir rutubetteki yoğunluk değeri $\left(\mathrm{g} / \mathrm{cm}^{3}\right)$,

Mr : Herhangi bir rutubetteki ağırlığı (g),

$V r$ : Herhangi bir rutubetteki hacim değeri $\left(\mathrm{cm}^{3}\right)$ ifade edilmektedir.

\section{Emprenye Uygulaması ve Retensiyon Tespiti}

Emprenye işlemi yoğunluk testi yapılan $20 \times 20 \times 20 \mathrm{~mm}$ (boyuna $x$ radyal $x$ teğet) boyutlarındaki örnekler üzerinde yapılmıştır. Emprenye işlemi öncesi odun örnekleri 60 으 sıcaklıkta 48 saat etüvde kurutularak fırın kurusu ağırlıkları belirlenmiştir $\left(m_{60^{\circ}} \mathrm{c}\right)$. Odun örneklerinin emprenyesinde vakumlu laboratuvar ölçekli emprenye kazanı kullanılmıştır.

Odun numuneleri ağzı açık kutular içerisine yerleştirilip, çözelti seviyesinin altında tutmak için örneklerin üzerine delikli bir aparat yerleştirilmiştir. Örnekler emprenye kazanına yerleştirilip 30 dakika süre ile 600 mmHg'ye eşdeğer ön vakum uygulanmıştır. Daha sonra, örnekler vakum altında iken içerisinde odun numunelerinin bulunduğu kutunun üzerine $\% 5$ konsantrasyon seviyesinde hazırlanan su bazı Tanalith-E (bakır azol) emprenye çözeltileri doldurulmuştur. Vakum işleminin ardından çözeltiler atmosfer basıncı altında 5 dakika bekletilerek emprenye sıvısının atmosferik basınç yardımıyla odun örneklerine nüfuzu arttırılmıştır.

Emprenye işlemi sonunda bütün örnekler hafif̧ce silinerek üzerlerindeki sıvı kalıntıları temizlenmiş ve hemen 0,01g hassasiyetteki terazide tartılarak emprenye sonrası yaş ağırlıkları $\left(m_{\text {yaş }}\right)$ belirlenmiştir. Deney numuneleri 2 hafta süre ile $20 \pm 2^{\circ} \mathrm{C}$ ve $\% 65 \pm 3$ bağıl nemde kondisyonlanmıştır.

Emprenye edilen örneklerin absorbe ettikleri çözelti miktarları TS 5723/1988 (Ahşap Koruma-Emprenye Maddesi Nüfuz Derinliğinin Tayini) standardında belirtilen yol takip edilerek eşitlik 2'deki formüle göre hesaplanmıştır (Bozkurt ve ark. 1993).

Retensiyon $=\frac{G \times C}{V} \times 10 \mathrm{~kg} / \mathrm{m}^{3}$

Eşitlikte;

$G=$ Örnek tarafından absorbe edilen çözelti miktarı ( $m_{\text {yaş}}{ }^{-}$ $\left.\mathrm{m}_{60 \circ \mathrm{C}}\right)(\mathrm{g})$

$\mathrm{m}_{60 \circ \mathrm{c}}=$ Emprenye öncesi ağırlık (g)

$\mathrm{m}_{\text {yaş }}=$ Emprenye sonrası yaş ağırlık (g)

$\mathrm{C}=$ Çözelti konsantrasyonu (5\%)

$V=$ Odun örneğinin hacmi $\left(\mathrm{cm}^{3}\right)$ dir.

\section{İstatistiki Analiz}

Aralama şiddeti, gövde kesit yüksekliği ve gövde yönünün dar yapraklı dişbudak odununun retensiyon ve yoğunluk değişimine etkisini belirlemek için verilere Çoğul Varyans Analizi (ANOVA) uygulanmıştır. Varyans analizi sonuçlarının önemli bulunması durumunda, ortalamaların karşılaştırılması amacıyla Duncan testi kullanılmıştır $(p<0.05)$. Ayrıca, yoğunluk ile retensiyon miktarı arasında ilişki olup olmadığının tespiti için Pearson korelasyon analizi yapılmıştır. Verilerin değerlendirilmesinde SPSS (ver. 21) paket istatistik programından yararlanılmış olup, sonuçlar $p<0.05$ düzeyinde istatistiki olarak farklı kabul edilmiştir. 


\section{BULGULAR}

\section{Odunların Emprenye Edilebilirliği}

Aralama kesimi uygulaması yapılmış ve gövdenin farklı yönlerine göre hazırlanmıs dişbudak odun örneklerinin emprenye edilebilirliğinin tespiti amacıyla yapılan retensiyon testleri bulgularına göre, aralama şiddeti, kesit yüksekliği ve gövde yönünün retensiyon miktarına etkisi önemli bulunmuştur $(p<0.05)$.

Aralama şiddetinin dar yapraklı dişbudak odununun emprenye edilebilirliği üzerindeki etki incelendiğinde, aralama şiddeti artmasıyla ortalama retensiyon miktarının da arttığı tespit edilmiştir. En yüksek retensiyon miktarı kuvvetli aralama müdahalesi yapılmış parsellerden alınan örneklerde tespit edişmiş olup, aralama müdahalesi yapılmamış kontrol örnekleri ile aralarında istatistiki olarak önemli düzeyde fark çıkmıştır (Şekil 1A). Aralamanın retensiyon miktarı üzerindeki olumlu etkisinin açıklanabilmesi için odunun emprenye edilebilirliği üzerinde etkili faktörlerin göz önünde bulundurulması gerekir. Odunun emprenye edilebilirliği üzerine, ağaç türü, yoğunluk, permeabilite, odun rutubeti ve emprenye kimyasalının yapısı gibi faktörler direk etkilidir. Ayrıca, yaz odunu-ilkbahar odunu oranı, odunun kesiş yönü, trahe/traheid lümen genişlikleri ve odundaki özel oluşumlar da (tül, geçit aspirasyonu v.b.) emprenye edilebilirlik üzerine etkili faktörler olduğu belirtilmektedir (Reinprecht 2016).
Aynı ağacın kuzey ve güneye bakan yönlerinden alınan örnekler üzerindeki emprenye edilebilirlik denemeleri sonucu, gövdenin güney yönündeki odununda retensiyon miktarı kuzeyden daha fazla olduğu tespit edilmiştir. (Şekil 1B). Bu farklılık istatistiki olarak önemli bulunmuştur. Daha önce yapılan bazı çalışmalarda da odunların farklı yönlerindeki emprenye edilebilirlik değerlerinde farklılıklar görülmüştür. Var ve ark. (2005) yaptıkları çalışmada benzer sonuçlar elde etmişler ve gövdenin güney yönünün kuzeye, doğu yönünün ise batıya nazaran daha fazla retensiyon miktarına sahip olduğunu ortaya koymuşlardır. Bu farklıı̆ı̆n belirtilen yönlerdeki odunun yoğunluk miktarındaki farklıııklardan kaynaklandığı belirtilmiştir.

Aynı ağaç odunu üzerinde farklı kesit yüksekliğinin retensiyon miktarı üzerine etkisi incelendiğinde, gövde kesit yüksekliği arttıkça odunun retensiyon miktarı azaldığı belirlenmiştir. Illk kesitten (0.30) alınan örneklerin, son kesitten $(13.30 \mathrm{~m})$ alınan örneklere göre \%32 daha fazla retensiyon düzeyine sahiptir. Göğüs yüksekliğindeki $(1.30 \mathrm{~m})$ odunun retensiyon miktarı son kesit yüksekliğinden yaklaşık \%11 daha yüksektir (Şekil 1C). Gövde kesit yüksekliğine bağlı olarak retensiyon miktarının değişiklik göstermesi yoğunluk değişimi ile açıklanabilir. Yapılan bu çalışmadaki yoğunluk testlerinde gövdenin aşağıdan yukarıya doğru yoğunluk değerlerinde artış görülmüştür. Yoğunluk ile retensiyon miktar arasındaki ters ilişki göz önüne alındığında, gövdenin aşağ kısmından yukarıya doğru gidildikçe retensiyon miktarının azalması beklenen bir durumdur.

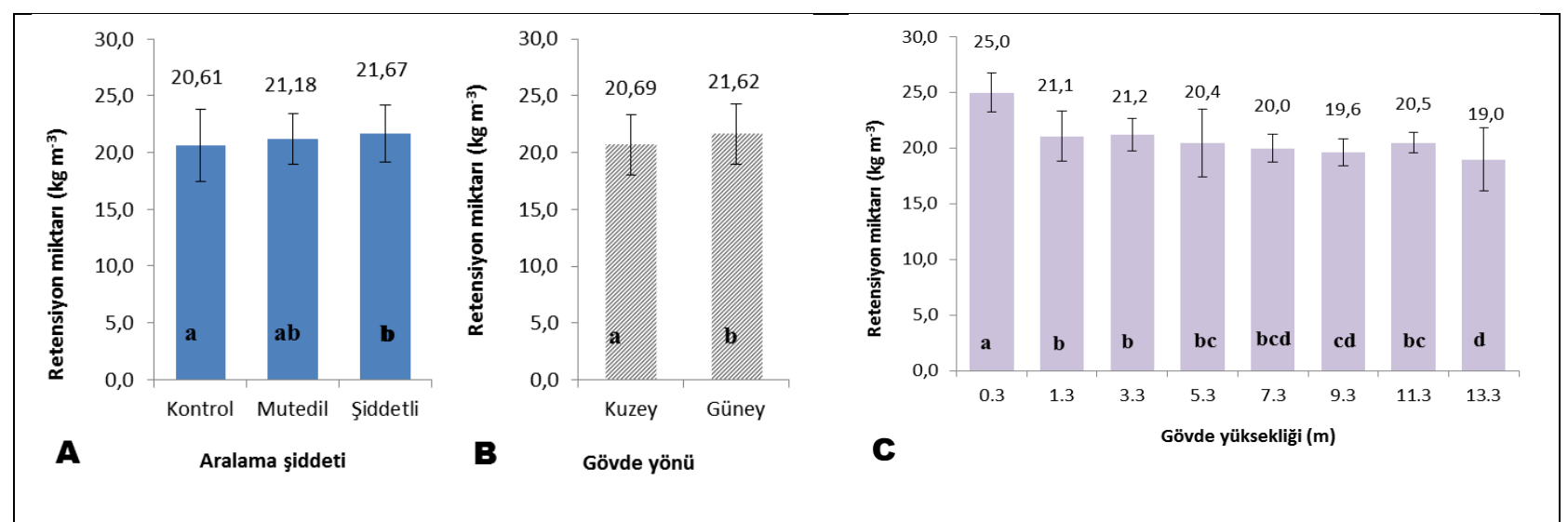

Şekil 1 Dar yapraklı dişbudak ağaçlarında aralama şiddetine (A), gövde yönüne (B) ve gövde boyuna (C) göre retensiyon miktarındaki değişim 
Diğer taraftan, aralama şiddeti $x$ kesit yüksekliği x gövde yönü etkileşiminin retensiyon miktarına etkisi de önemli bulunmuştur ( $p<0.05$; Çizelge 1). Etkileşim çizelgesi incelendiğinde, her üç grupta da 0.30 kesit yüksekliğindeki retensiyon miktarları yaklaşık 22-27 $\mathrm{kg} / \mathrm{m}^{3}$ seviyelerinde olduğu görülmektedir. Bu değerler diğer kombinasyonlara göre daha yüksek seviyeler olup istatistiki olarak diğerlerinden farklı çıkmıştır.

Çizelge 1 Aralama şiddeti x gövde yüksekliği x gövde yönü etkileşiminin dişbudak retensiyon miktarı üzerine etkisi [ortalama (standart sapma)]

\begin{tabular}{|c|c|c|c|c|c|c|c|}
\hline \multirow[t]{2}{*}{ G.Y (m) } & \multirow[t]{2}{*}{ O.Y } & \multicolumn{6}{|c|}{ Aralama şiddeti / Retensiyon miktarı $\left(\mathrm{kg} / \mathrm{m}^{3}\right)$} \\
\hline & & \multicolumn{2}{|c|}{ Kontrol } & \multicolumn{2}{|c|}{ Mutedil aralama } & \multicolumn{2}{|c|}{ Şiddetli aralama } \\
\hline \multirow[t]{2}{*}{0.30} & K & $26,85(0,70)$ & $I^{* *}$ & $24,56(0,99)$ & $j k l^{* *}$ & $25,36(0,32)$ & $i j k l^{* *}$ \\
\hline & G & $25,80$ ( 1,99$)$ & $k l$ & $22,14(0,73)$ & fghi & $25,37(0,59)$ & $j k l$ \\
\hline \multirow[t]{2}{*}{1.30} & K & $19,57(1,78)$ & bcde & $21,35(1,51)$ & defgh & $22,98(0,49)$ & fghi \\
\hline & G & $20,68(2,20)$ & bcdefg & $21,56(1,82)$ & hijk & $21,90(2,41)$ & efgh \\
\hline \multirow[t]{2}{*}{3.30} & K & $21,12(1,61)$ & cdefgh & $21,84(0,62)$ & bcde & $21,49(0,79)$ & defgh \\
\hline & G & $20,55(1,38)$ & bcdef & $19,63(1,69)$ & efgh & $22,68(0,96)$ & fghi \\
\hline \multirow[t]{2}{*}{5.30} & K & $15,86(1,24)$ & $a$ & $*$ & & $22,04(1,10)$ & efgh \\
\hline & G & $20,69(1,25)$ & bcdefg & $*$ & & $23,17(1,07)$ & ghij \\
\hline \multirow[t]{2}{*}{7.30} & K & $19,55(0,93)$ & bcde & $21,37(0,86)$ & cdefgh & $19,62(0,81)$ & bcde \\
\hline & G & $19,56(0,87)$ & bcde & $21,11(1,24)$ & cdefgh & $18,80(0,35)$ & $b c$ \\
\hline \multirow[t]{2}{*}{9.30} & K & $*$ & & $20,46(0,72)$ & $b c$ & $*$ & \\
\hline & G & $*$ & & $18,79(0,97)$ & bcdef & $*$ & \\
\hline \multirow[t]{2}{*}{13.30} & K & $18,11(1,33)$ & $b$ & $20,53(0,96)$ & bcdef & $20,13(1,01)$ & bcdef \\
\hline & G & $19,03(1,27)$ & $b c$ & $20,43(1,01)$ & $b c d e f$ & $18,73(5,73)$ & $b c$ \\
\hline \multicolumn{2}{|c|}{ Ortalama } & $20,61(0,99)$ & & $21,18(2,51)$ & & $21,67(2,27)$ & \\
\hline
\end{tabular}

* Örneklendirilemeyen kısım, G.Y: Gövde yüksekliği, O.Y: Odunun gövde yönü, **Aynı sütundaki aynı harfler arasında istatistiksel olarak anlamlı fark yoktur $(p<0.05)$.

\section{Yoğunluk Değişimi}

Doğal (aralama kesimi yapılmamış) dişbudak kontrol örneklerinin ortalama yoğunluğu $0,70 \mathrm{~g} / \mathrm{cm}^{3}$ olarak tespit edilmiştir. Doğal yetişen dişbudak odununun yoğunluğuna ilişkin daha önce yapılan çalışmalarda; Bozkurt (1986) 0,450-0,860 $\mathrm{g} / \mathrm{cm}^{3}$ arasında değiştiğini, Şahin (2013) $0.77 \mathrm{~g} / \mathrm{cm}^{3}$, Tırak (2014) $0,728 \mathrm{~g} / \mathrm{cm}^{3}$ olduğunu belirtmişlerdir. Yapılan bu çalışmada yoğunluğun doğal dişbudak odun yoğunluğunun $(0,70$ $\mathrm{g} / \mathrm{cm}^{3}$ ) daha önce yapılan çalışmalardan bir miktar düşük çıkması yoğunluk ölçümlerinin ağacın dip kısmından itibaren alınması ve boyuna yönde yedi farklı nokta ve kuzey güney bölümlerinin ortalaması alınmasından kaynaklandığı düşünülmektedir. Ayrıca ağaçların yetişme yerleri, toprak türü, genç odun ve reaksiyon odunu oluşumu gibi özelliklerinde yoğunluk üzerinde etkili faktörler olduğu belirtilmektedir (Bozkurt ve Erdin 2011).

Odun yoğunluğu kontrol ve mutedilde benzer iken, kuvvetli aralanan parseldeki odun yoğunluğu diğerlerine göre yaklaşık \%5 daha düşüktür ( $p<0.05$; Şekil $2 \mathrm{~A}$ ). Daha önce yapılan doğal ve plantasyon ormanlarında yapılan bir çalışmada, dişbudak odunlarının dikim aralığı artışı ile birlikte yoğunluğun azaldığı görülmüştür. En yüksek yoğunluk ise doğal dişbudak ormanlarında tespit edilmiştir (Şahin 2013). Birçok çalışma, halkalı traheli geniş yapraklı ağaçlarda yüksek odun yoğunluğunun hızlı büyüme ile ilgili olduğunu göstermiştir (Panshin ve de Zeeuw 1980; Van Buistenen 1989; Tsoumis 1991). Wheeler (1987) bunun nedenini daha yoğun ve daha az traheye, daha fazla lif hücresine sahip yaz odununun yıllık halka genişliği ile artmasına bağlamaktadır. Yapılan silvikültürel müdahaleler ile birlikte büyüme hızları arttırıldığı bilinmektedir. Ancak halkalı traheli odunlarda büyüme hızı belli limitler içinde kalması durumunda yoğunluğu arttırmaktadır. Çünkü bu tip ağaçlarda ekstrem büyüme hızı anormal derecede ince çeperli lif ve yüksek oranda paranşim hücrelerinin oluşumuna sebep olmakta ve yoğunluğun azalması meydana gelmektedir (Jane ve ark. 1970).

Gövdenin kuzey ve güney yönlerindeki odunlarında yoğunluk farkı anlamlı ancak çok küçük miktardadır (\%1.2). Yoğunluğun gövdenin farklı yönlerinde değişiklik göstermesi, yıllık halklardaki ilkbahar ve yaz odunu iştirak oranlarının farklılık göstermesinden kaynaklandığı belirtilmektedir (Var ve ark. 2005). İlkbahar odunu ince çeperli ve geniş lümenli bir yapıya sahip olduğundan, yıllık halkadaki iştirak oranı artmasıyla birim hacimdeki madde 
miktarında azalma meydana gelmesi ve yoğunlukta azalma olması söz konusudur (Merev 2003).

Ayrıca gövde kesit yüksekliği artıkça genellikle yoğunlukta bir artma olduğu söylenebilir. Gövdenin $13.3 \mathrm{~m}$ yüksekliğindeki odunun 0.3 m'deki odundan yaklaşık $\% 25$, göğüs yüksekliğindeki odundan ise yaklaşık \%10 daha yoğundur $(p<0.05)$. Gövdenin 1.3, 3.3, 5.3 ve $7.3 \mathrm{~m}$ yüksekliklerindeki odunların yoğunlukları aynıdır (Şekil 2C). Bilindiği gibi yapraklı ağaçlarda kök odunu gövde odununa göre daha hafif olup, gövde odununa göre yaklaşık \%20 daha az yoğundur.

Çizelge 2. Aralama şiddeti x gövde yüksekliği x gövde yönü etkileşiminin dişbudak odunun yoğunluğu üzerine etkisi[ortalama (stant. sapma)]

\begin{tabular}{|c|c|c|c|c|c|c|c|}
\hline \multirow{3}{*}{$\begin{array}{c}\text { G.Y (m) } \\
0.30\end{array}$} & \multirow{3}{*}{$\begin{array}{c}O . Y \\
K\end{array}$} & \multicolumn{6}{|c|}{ Aralama şiddeti / Odun yoğunluğu $\left(\mathrm{g} / \mathrm{cm}^{3}\right)$} \\
\hline & & \multicolumn{2}{|c|}{ Kontrol } & \multicolumn{2}{|c|}{ Mutedil aralama } & \multicolumn{2}{|c|}{ Şiddetli aralama } \\
\hline & & $0,53(0,02)$ & $a^{* *}$ & $0,58(0,02)$ & $b^{* *}$ & $0,59(0,01)$ & $b c^{* *}$ \\
\hline & G & $0,57(0,02)$ & $b$ & $0,59(0,04)$ & $b c$ & $0,60(0,02)$ & $b c$ \\
\hline \multirow[t]{2}{*}{1.30} & K & $0,72(0,02)$ & $i j k l$ & * & & $0,66(0,01)$ & def \\
\hline & G & $0,68(0,03)$ & efgh & $0,79(0,08)$ & $n$ & $0,63(0,02)$ & $c d$ \\
\hline \multirow[t]{2}{*}{3.30} & K & $0,71(0,01)$ & hij & $0,69(0,01)$ & fghi & $0,67(0,01)$ & efg \\
\hline & G & $0,69(0,02)$ & ghi & $0,70(0,03)$ & ghi & $0,65(0,01)$ & de \\
\hline \multirow[t]{2}{*}{5.30} & K & $0,79(0,02)$ & $n$ & $0,66(0,02)$ & def & $0,63(0,01)$ & efgh \\
\hline & G & $0,69(0,01)$ & fghi & $0,67(0,01)$ & $e f g$ & $0,67(0,01)$ & $e f g$ \\
\hline \multirow[t]{2}{*}{7.30} & K & $*$ & & $0,69(0,03)$ & fghi & $0,71(0,01)$ & hij \\
\hline & G & $*$ & & $0,71(0,01)$ & hij & $0,70(0,02)$ & ghi \\
\hline \multirow[t]{2}{*}{9.30} & K & $0,76(0,01)$ & $\operatorname{Imn}$ & $0,75(0,01)$ & $\operatorname{Imn}$ & $0,71(0,01)$ & hijk \\
\hline & G & $0,75(0,02)$ & $\mathrm{klm}$ & $0,70(0,01)$ & ghi & $0,69(0,01)$ & fghi \\
\hline \multirow[t]{2}{*}{13.30} & K & $0,79(0,03)$ & $n$ & $0,75(0,01)$ & $j k / m$ & $0,72(0,01)$ & $j k / m$ \\
\hline & G & $0,75(0,01)$ & $m n$ & \multirow{2}{*}{\multicolumn{2}{|c|}{$\begin{array}{c}0,75(0,02) \quad \mathrm{k} / \mathrm{m} \\
0,69\end{array}$}} & $0,70(0,02)$ & hij \\
\hline \multicolumn{2}{|c|}{ Oratalama } & \multicolumn{2}{|c|}{0,70} & & & 0,67 & \\
\hline
\end{tabular}

* Örneklendirilemeyen kısım. G.Y: Gövde yüksekliği, O.Y: Odunun gövde yönü, **Aynı sütunlardaki aynı harfler arasında istatistiksel olarak anlamlı fark yoktur $(p<0.05)$.

Aralama kesimi $x$ kesit yüksekliği etkileşimi incelendiğinde, her üç aralama kesimi grubunda 0.30 kesit yüksekliğindeki odun yoğunluğu diğer kesit yüksekliklerine göre düşük çıkmış olup, bu fark istatistiki olarak anlamlı bulunmuştur (Çizelge 2). Gövde yönü ayrımı yapılmaksızın gövdenin alt kısmından tepe kısmına doğru gittikçe ortalama yoğunluk miktarının arttığı görülmektedir (Şekil 2).
Halkalı traheli odunlarda, yoğunluk Kaliforniya ak meşesinde (Quercus lobata) ağacın alt kısımlarında daha yüksek çıkarken, Oregon'da yetişen ak meşelerde (Quercus garryana) ağacın alt kısımlarında düşük yoğunluklar tespit edilmiştir (Benson ve ark. 1958).

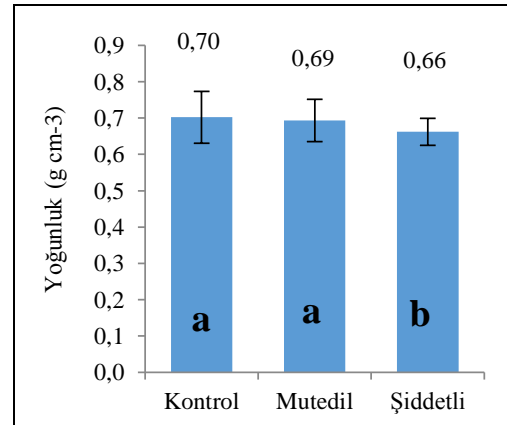

A

Aralama șiddeti

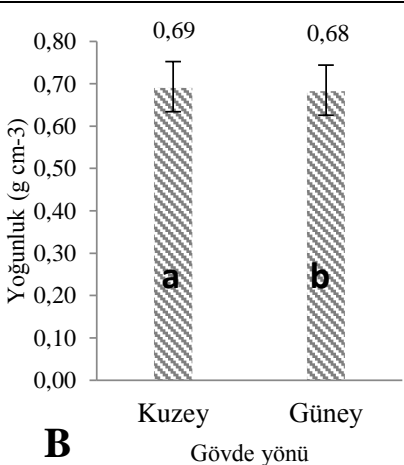

Gövde yönü

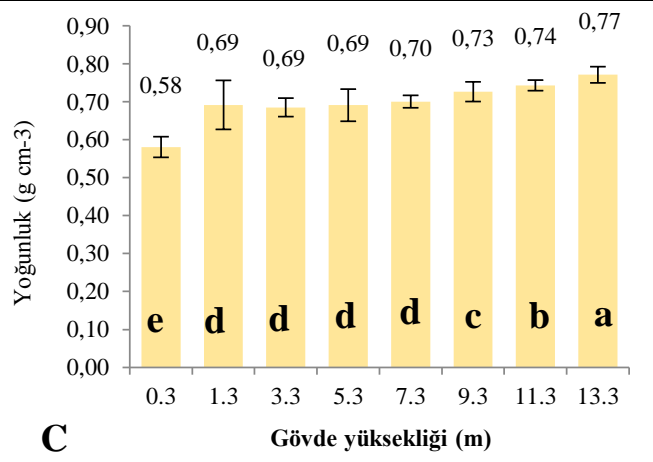

Şekil 2 Dar yapraklı dişbudak ağaçlarında aralama şiddetine (A), gövde yönüne (B) ve gövde boyuna (C) göre odun yoğunluğundaki değişim 
İşlemler arasında ayrım yapılmaksızın odun yoğunluğu ile retensiyon miktarı arasında ters yönde ilişki bulunmuştur $(R=-0,67, p<0.001)$. Bu ilişkinin gücü kontroldeki ağaçlarda daha yüksek ( $R=-0.903, p<0.001)$ iken, mutedil $(R=-0.558$, $p<0.001)$ ve kuvvetli aralanan parsellerdeki ağaçlarda $(R=-$ $0,546, p<0.001)$ daha düşüktür. Ayrıca korelasyonun gücü gövdenin güney yönüne $(R=-0.524, p<0.001)$ nazaran kuzey yönünde $(R=-0.801, p<0.001)$ daha güçlüdür. Yoğunluk ile retensiyon miktarı arasındaki ilişki, odundaki boşluk miktarı ile ilişkilendirilebilir. Boşluk miktarındaki artış ile odunun alabileceği emprenye maddesi miktarı da artış göstermektedir. Boşluk miktarı ise odunun yoğunluğunu doğrudan etkileyen bir faktördür. Boşluk miktarı artışı ile birlikte odunun yoğunluğu azalma göstermektedir. Yani boşluk miktarının artması, yoğunluğun azalmasına etki ederken retensiyon miktarının artışına sebep olmaktadır (Bozurt ve Erdin 1993).

\section{SONUÇ}

Aralama şiddetinin dar yapraklı dişbudak odunun yoğunluğu ve emprenye edilebilirliği üzerine etkileri incelendiğinde, aralama kesimi yapılmamış doğal meşcereden alınan örnekler ile mutedil ve şiddetli aralama yapılmış odun örnekleri arasında yoğunluk ve emprenyede retensiyon miktarları arasında düşük düzeyde olmakla birlikte istatistiki olarak anlamlı farklılık tespit edilmiştir. Aralamanın şiddeti artması ile birlikte odun yoğunluğunda azalma, retensiyon miktarında ise artma meydana geldiği belirlenmiştir.

Kesiş yüksekliği bakımından odun yoğunluğu ve emprenye edilebilirlik irdelendiğinde, doğal, mutedil, şiddetli ve bunların tümünün ortalaması ayrı ayrı göz önüne alındığında, gövdenin altında tepe noktasına çıkıldıkça odunu yoğunluğunda \%25'lere varan artma, retensiyon miktarında ise yaklaşık \%30'lara varan azalma olduğu sonucuna varılmıştır. Gövdenin en altı ile en üstü arasındaki yoğunluk farklı kontrol ve mutedil aralamada şiddetli aralamaya göre daha belirgin olduğu tespit edilmiştir.

Gövde yönünün dişbudak odununun retensiyon ve emprenye edilebilirliği üzerine etkisine bakıldığında, gövdenin kuzeye bakan kısmının güneye bakan kısmına göre nispeten daha yoğun, retensiyon miktarı ise daha az olduğu sonucuna varılmıştır.

Tüm bu sonuçlar birlikte istatistiki olarak incelendiğinde, retensiyon miktarı ile emprenye maddesinin retensiyon miktarı arasında ters yönlü bir korelasyon olduğu sonucuna varılmıştır. Odunun yoğunluğu artmasıyla birlikte retensiyon miktarında azalmalar olduğu tespit edilmiştir.

Elde edilen sonuçlara göre, dar yapraklı dişbudak odunlarında aralama kesimi yapılması odunun fiziksel özelliklerinden yoğunluk ve permeabiliteyi etkilediği ve her ne kadar odunun yoğunluğunu düşürse de emprenye edilebilirliği üzerinde olumlu etki yaptığı söylenebilir. Ayrıca odunlardaki kesiş yüksekliği ve gövde yönünün de odunun fiziksel özelliklerinden yoğunluk ve permeabilite üzerinde etkili birer faktör olduğu görülmektedir.

\section{KAYNAKLAR}

Anonim (2015) Türkiye orman varlığı. Orman ve Su İşleri Bakanlığı, Orman Genel Müdürlüğü, Ankara.

Barefoot AC, Hitchings RG, Ellwood EL,Wilson EH (1970) The relationship between loblolly pine fiber morphology and kraft paper properties. North Carolina Agricultural Experimental Station Technical Bulletin No. 202. Raleigh, NC., North Carolina State University.

Benson PH, Dohr AW, Drow JT (1958) Some properties of California white oak and Oregon oak, USDAFS Forest Products Laboratory Report 2135, Madison Wisconson.

Fraxigen (2005) Ash species in Europe: biological characteristics and practical guidelines for sustainable use. Oxford Forestry Institute, University of Oxford.

Bozkurt AY, Göker Y, Erdin N (1993) Emprenye Tekniği, İstanbul Üniversitesi Orman Fakültesi Yayınları.

Bozkurt AY, Erdin N (1989) Ağaç malzeme kalitesi ve silvikültürel tedbirler, İstanbul Üniversitesi Orman Fakültesi Dergisi, Seri B, 39:1-13.

Bozkurt Y, Erdin N (1995) İğne yapraklı ve yapraklı ağaç odunlarında tanım özellikleri (Odun anatomisi II), i..Ü. Yayın No: 3907, Fen Bilimleri Enstitüsü Yayın No: 6.

Bozkurt Y, Erdin (2011) Ağaç teknolojisi, İstanbul Üniversitesi, Orman Fakültesi, i.ü. Yayın No: 5029, O.F. Yayın No: 445.

Cicek E, Yilmaz F, Özbayram AK, Efe M, Yilmaz M, Usta A (2013) Effects of thinning intensity on the growth of narrow-leaved ash (Fraxinus angustifolia subsp. oxycarpa) plantations, Turkish Journal of Agriculture and Forestry, 37: 97-104.

Çiçek E (2002) Adapazarı-Süleymaniye Subasar Ormanında Meşcere Kuruluşları ve Gerekli Silvikültürel Önlemler, İstanbul Üniversitesi Fen Bilimleri Enstitüsü, Doktora Tezi, İstanbul, $138 \mathrm{~s}$.

Çiçek E (2004) Silvicultural evaluation of some stand characteristics in narrow-leaved ash (Fraxinus angustifolia Vahl.) plantations, Gazi Üniversitesi Orman Fakültesi Dergisi, 4: 205-219. 
Güller B, Gürlevik N (2005) Ormancilıkta Uygulanan Aralama Müdahalelerinin Odun Özellikleri Üzerine Etkisi, I. Çevre ve Ormancilık Şurası, Antalya Tebliğler kitabı 3. Cilt, 1058-1066.

Jane FW, Wilson K, white DJB (1970) The Structure of Wood, London, Adam \& Charles Black.

Jessome AP (1977) Strength and related properties of woods grown in Canada. Eastern Forest Products Laboratory, Ottawa, Ontario. Forestry Technical Report 21, Ottawa.

Kaygın AT (2007) Endüstriyel Odun Zararlıları. Nobel Yayın No:1082, 1. Basım, Fen ve Biyoloji Yayınları Dizisi 31, Ankara.

Kremer D, Cavlovic J, Bozic M (2006) Growth characteristics of introduced green ash (Fraxinus pennylvanica Marshall) and narrow-leaved ash (Fraxinus angustifolia L.) in lowland forest region in Croatia, New Forests 31: 211-224.

Merev N (1984) Odun Anatomisi ve Odun Tanıtımı Ders Notları. Karadeniz Teknik Üniversitesi, Orman Fakültesi Yayın No: 88, Trabzon

Panshin AJ, De Zeeuw C (1980) Textbook of wood technology, Mc Graw-Hill, Inc. Fourth Edition, p.736, New York.

Reinprecht L (2016) Wood Deterioration, Protection and Maintenance, Wiley-Blackwell; First Edition, 376 p.

Richardson BA (1978) Wood Preservation, The Construction Press, Lancaster, England, $238 \mathrm{p}$.

Şahin Hi (2013) Isıl işlemin doğal ve plantasyon ormanlarında yetişen dişbudak (Fraxinus angustifolia Vahl.) odunlarının bazı teknolojik özelliklerine etkisi. Düzce Üniversitesi Fen Bilimleri Enstitüsü, Doktora Tezi, Düzce, $258 \mathrm{~s}$.

Şahin Hi, Güler, C (2015). Hızlı gelişen dar yapraklı dişbudak (Fraxinus angustifolia Vahl) odununun orman ürünleri endüstrisinde değerlendirilmesi, Gazi Üniversitesi Fen Bilimleri Dergisi Part:C, Tasarım ve Teknoloji, 3(1): 357-365.

Şahin Hi, Güler, C (2018). Effect of heat treatment on the dimensional stability of ash (Fraxinus angustifolia Vahl.) wood, Forestist 68(1): 42-52.

Tırak, K (2014) Doğal meşcerelerde ve plantasyonlarda yetişen dişbudak, kızılağaç odunları yapısal özelliklerinin karşılaştırılması, İstanbul Üniversitesi Fen Bilimleri Enstitüsü, Doktora Tezi, İstanbul $343 \mathrm{~s}$.

TS 5723 (1988) Ahşap koruma-emprenye maddesi nüfuz derinliğinin tayini, Türk Standartları Enstitüsü, Ankara.

Tsoumis G (1991) Science and technology of wood; structure, properties, utilization, Van Nostrand Reinhold, New York.

van Buistenen JP (1982) Fibers for the future, Tappi 65:10-12

Var AA, Önder A, Samim Y (2005) Anadolu karaçamında [Pinus nigra arnd. Subsp. Pallasiana (lamb.) Holmboe] Imersol aqua ${ }^{\circledR}$ absorpsiyonunun ağacın yönlerine göre değişimi, Süleyman Demirel Üniversitesi Orman Fakültesi Dergisi Seri: A, 1: 143-152.

Wheeler EA (1987) Anatomical and biological properties of juvenile wood in conifers and hardwoods. 41st Ann Meet FPRS Louisville, Kentucky.

Yalcin M, Sahin HI (2015) Changes in the chemical structure and decay resistance of heat-treated narrow-leaved ash wood. Maderas Ciencia y tecnología 17: 435-436

Yaltırık F (1978) Türkiye'deki doğal Oleaceae taksonlarının sistematik revizyonu, İstanbul Üniversitesi Orman Fakültesi Yayınları, No:250, $118 \mathrm{~s}$.

Zobel BJ, Van Buijtenen JP (1989) Wood variation-its causes and control, Springer Verlag, New York, 363 p.. 